\title{
EVALUATION OF A PELLETED FORMULATION OF MOMORDICA CHARANTIA ON THE CONTROL OF GOAT VERMINOSIS IN THE BRAZILIAN SEMIARID
}

\author{
AVALIAÇÃO DE UMA FORMULAÇÃO PELETIZADA DE MOMORDICA CHARANTIA NO \\ CONTROLE DA VERMINOSE DE CAPRINOS NO SEMIÁRIDO BRASILEIRO
}

\author{
L. R. B. MELO' ${ }^{1}$; V. L. R. VILELA ${ }^{1}$; D. V. O. SOUTO ${ }^{1}$; G. L. SILVEIRA ${ }^{1}$; T. F. FEITOSA ${ }^{1}$; \\ A. C. R. ATHAYDE ${ }^{1}$
}

\section{SUMMARY}

The aim was to develop a pelleted formulation of Momordica charantia (São Caetano Melon) to improve its palatability, administration, and to test its anthelmintic efficacy in naturally infected goats in the semiarid region of Paraíba, Brazil. Ten animals were used in a pre-experiment, where 20 formulations containing the plant were tested. After choosing the most palatable one, 18 six months-old, male Boer goats, were divided into three groups and evaluated during 28 days: Group 1, received daily a formulation of pellets composed by $60 \%$ of $M$. charantia $+5 \%$ of emulsifier $+35 \%$ of molasses powder at a dose of $1 \mathrm{~g} / \mathrm{kg}$ of live weight; Group 2, received the same formulation daily in the dose of $2 \mathrm{~g} / \mathrm{kg}$ of live weight; and Group 3, received no phytotherapy treatment (Control group). Fecal samples were collected to carry out the EPG and fecal cultures and the animals were weighed at days zero, seven, 14, 21 and 28. The treatments with $M$. charantia pellets were unsatisfactory in all collections, and there was no statistical difference $(\mathrm{P}>0,05)$ among the groups. On day 28, the groups treated with $1 \mathrm{~g} / \mathrm{kg}$ and $2 \mathrm{~g} / \mathrm{kg}$ showed an increase in EPG of $143 \%$ and $100 \%$, respectively. Haemonchus sp. was the most prevalent genus in the fecal cultures. A statistical difference was not observed $(\mathrm{P}>0,05)$ in the animal's weight. The pelleted formulation of $M$. charantia was ineffective to control of gastrointestinal helminthiosis of naturally infected goats in the Brazilian semiarid.

KEY-WORDS: Gastrointestinal helminthosis. Goat farming. Pellets. Phytotherapy. São Caetano Melon.

\section{RESUMO}

Objetivou-se desenvolver uma formulação peletizada de Momordica charantia (Melão de São Caetano) para melhorar sua palatabilidade e administração, bem como testar sua eficácia anti-helmíntica em caprinos naturalmente infectados no semiárido da Paraíba, Brasil. Foram utilizados dez animais em um pré-experimento, onde foram testadas 20 formulações contendo a planta. Após a escolha da mais palatável, 18 caprinos machos da raça Boer, com seis meses de idade, foram divididos em três grupos e avaliados durante 28 dias: Grupo 1, animais receberam diariamente uma formulação de péletes compostos por $60 \%$ de $M$. charantia $+5 \%$ de emulsificante $+35 \%$ de pó de melaço, na dosagem de $1 \mathrm{~g} / \mathrm{kg}$ de peso vivo; Grupo 2, receberam a mesma formulação diariamente na dosagem de $2 \mathrm{~g} / \mathrm{kg}$ de peso vivo e o Grupo 3 não recebeu tratamento fitoterápico, servindo como grupo Controle. Foram coletadas amostras de fezes para realização dos OPG e coproculturas e realizadas as pesagens dos animais nos dias zero, sete, 14, 21 e 28 . Os tratamentos com péletes de $M$. charantia foram insatisfatórios em todas as coletas, não havendo diferença estatística ( $\mathrm{P}>0,05)$ entre os grupos. No dia 28, os grupos tratados com $1 \mathrm{~g} / \mathrm{kg}$ e $2 \mathrm{~g} / \mathrm{kg}$ apresentaram aumento no OPG de, respectivamente, $143 \%$ e $100 \%$. Haemonchus sp. foi o gênero mais prevalente nas coproculturas. Também não foi observada diferença estatística $(\mathrm{P}>0,05)$ no peso dos animais. A formulação peletizada de $M$. charantia não foi eficaz no controle das helmintoses gastrintestinais de caprinos naturalmente infectados no semiárido Brasileiro.

PALAVRAS-CHAVE: Caprinocultura. Fitoterapia. Helmintoses Gastrointestinais. Melão-de São-Caetano. Péletes.

\footnotetext{
${ }^{1}$ Post-graduate Program in Veterinary Medicine, UFCG, Patos, PB, Brazil;

* Author for correspondence. Federal University of Campina Grande - UFCG, Bairro Jatobá - Caixa Postal 64 - Patos, PB, Brazil. Postcode: 58700-970; E-mail: lidioricardolrbm@hotmail.com
} 


\section{INTRODUCTION}

Goat farming is a subsistence source for the rural population in Brazil, with higher incidence in the semi-arid areas of the Northeast. It offers the goatfarmers various means of obtaining profit with the production of meat, skin, milk and dairy products.

The many advantages of small ruminants rearing are threatened by factors that limit the good performance of this activity. In the Northeast, as well as in other regions of Brazil, gastrointestinal endoparasites can be observed, which are responsible for high economic losses and serious damage to the goats, such as anemia, weight loss, a decrease in food intake, reduction in the production of meat and milk (MOLENTO, 2004, LIMA et al., 2010). In the state of Paraíba the "Sertão" region presents high prevalence of gastrointestinal helminthiasis in goats (VIEIRA et al., 2014).

Aiming to reduce the financial losses caused by gastrointestinal helminths, the farmers have been administering anthelmintics in an uncontrolled manner, with sub or super-doses and excessive dosing, developing anthelmintic resistance to the various chemical compounds available in the market (MELO et al., 2013).

Hence, the search for new alternatives for the control of gastrointestinal helminthiasis has been widely stimulated, for instance the studies with anthelmintic plants, which may be of low cost to the producers and not leave residues in meat, milk and in the environment (VILELA et al., 2009). According to Getachew (1999), what grants the plant an anthelmintic character is the high levels of condensed tannins. However, these tannins are the reason the plants present a bitter taste, which reduces their palatability, thus hindering its administration to animals.

The Momordica charantia Linnaeus (1763), is a plant which invades crops and that develops as a climbing plant, mostly in fences, being found throughout Brazil during the rainy season. In addition to other medicinal properties, it presents a proven in vivo and in vitro anthelmintic activity (ALMEIDA et al., 2007, CORDEIRO et al., 2010, SOUSA et al., 2010, BRITO-JÚNIOR et al., 2011).

There was the need to develop a pelletized formulation of $M$. charantia, to improve its palatability, facilitating its administration to animals. Thus, the objective of this study was to test the anthelmintic action of a pelletized formulation of $M$. charantia (São Caetano Melon) in naturally infected goats in the semiarid region of Paraíba.

\section{MATERIAL AND METHODS}

The present study was submitted to the Ethics Committee and was granted execution authorization under registration number 121/2016.

The experiment was carried out between the months of June and August 2012. The leaves of $M$. charantia were collected in rural area of the municipality of Gado Bravo-PB in the months of April and May 2012. Parts of the plant were transformed into exsiccatae for a botanical identification and deposited in the "Caririense Dárdano de Andrade Lima" Herbarium of the Regional University of the Cariri URCA, with the registration No. 3272.

The plant material was placed for air drying for 48 hours, subsequently ground and weighed. For the pelletizing were mixed the powder of the São Caetano Melon leaves, molasses powder and emulsifier powder at different concentrations, and for each $10 \mathrm{~g}$ of the mixture, were added $10 \mathrm{~mL}$ of distilled water. Subsequently, the mass was placed on the silicone molds of 2,5 $\times 2,0 \times 0,8 \mathrm{~cm}$ and taken to the forced-ventilation chamber at $40^{\circ} \mathrm{C}$ for 24 hours. After this period, the pellets were taken out of the molds and weighed.

Various mixtures with different concentrations of the ingredients were offered to the animals. For the choice of the most palatable formulation, the time of ingestion of the pellets was measured and the maximum quantity ingested by the animals, preference was given to those mixtures with a higher concentration of $M$. charantia powder. The selected formulation was as follows: $60 \%$ of $M$. charantia + $35 \%$ of molasses $+5 \%$ of emulsifier.

For the determination of the dosage of pellets to be administered, the calculation was carried out based on Almeida et al. (2007), in which was administered 90 $\mathrm{g}$ of green leaf per $20 \mathrm{~kg}$ of live weight.

\section{Test of anthelmintic effectiveness}

For the anthelmintic evaluation of the most palatable formulation, 18 Boer goats were used, with ages ranging between six and eight months, naturally infected with gastrointestinal helminths. The animals were kept in intensive rearing system, receiving protein-energy supplementation, complete mineral mixture and water ad libitum.

The animals were divided into three groups: Group I - Animals that received orally, during 28 consecutive days, a dosage of $1 \mathrm{~g} / \mathrm{kg}$ of live weight of the pelletized formulation; Group II - received orally, during 28 days, the dosage of $2 \mathrm{~g} / \mathrm{kg}$ live weight of pelletized formulation; Group III - animals that did not receive anthelmintic treatment during the experiment, serving as control group.

Fecal samples were collected directly from the ampullae per rectum of the animals on days zero and seven, 15, 21 and 28 days post-treatment. The EPG (eggs per gram) were processed, according to the Gordon and Whitlock technique, modified (1939), and the fecal cultures, according to the technique described by O' Sullivan \& Roberts (1950). To evaluate the ponderal development, the animals were weighed at every seven days.

\section{Statistical Analysis}

A reduction in the Fecal Egg Count (FECR) was determined according to Coles et al. (1992). The EPG and weight data were submitted to the Analysis of Variance and Tukey's Test at 5\% probability. The EPG values were transformed into $\log (\mathrm{x}+1)$, and however, are present in the table as arithmetic averages of the non-transformed values. 


\section{RESULTS AND DISCUSSION}

An increase of the EPG was found throughout the experiment in all the experimental groups, resulting in a negative FECR (Table 1).

It was observed that the experimental treatments $M$. charantia pellets were unsatisfactory in all the sample collections, and there was no statistical difference $(\mathrm{P}>0,05)$, when compared to the control group. When assessing the FERC values, it is noticed that even after 28 days of treatment with plant pellets, the groups treated with $1 \mathrm{~g} / \mathrm{kg}$ to $2 \mathrm{~g} / \mathrm{kg}$ presented an increase in EPG of, respectively $143 \%$ and $100 \%$. A statistical difference $(\mathrm{P}>0,05)$ was not observed between the groups treated with the $M$. charantia pellets and the control group. This was the first report of the ineffectiveness of this plant, which could be due to its pelletizing. However, this pelletizing process does not present procedures capable of affecting their chemical constituents.

Table1 - EPG averages and FECR percentage of goats naturally infected by gastrointestinal nematodes treated with $M$. charantia pellets in Brazilian semiarid.

\begin{tabular}{lccccccccc}
\hline Groups & Day 00 & $\begin{array}{c}\text { Day } \\
07\end{array}$ & $\begin{array}{c}\text { FERC } \\
(\%)\end{array}$ & Day 15 & $\begin{array}{c}\text { FERC } \\
(\%)\end{array}$ & Day 21 & $\begin{array}{c}\text { FERC } \\
(\%)\end{array}$ & Day 28 & $\begin{array}{c}\text { FECR } \\
(\%)\end{array}$ \\
\hline $\begin{array}{l}M . \text { charantia } \\
\text { g } / \mathrm{kg}\end{array}$ & $1160^{\mathrm{Aa}}$ & $2440^{\mathrm{Aa}}$ & $-78,6$ & $1580^{\mathrm{Aa}}$ & -58 & $2180^{\mathrm{Aa}}$ & $-92,1$ & $2560^{\mathrm{Aa}}$ & -143 \\
$\begin{array}{l}\text {. charantia } \\
2 \mathrm{~g} / \mathrm{kg}\end{array}$ & $940^{\mathrm{Aa}}$ & $1940^{\mathrm{Aa}}$ & $-42,0$ & $1360^{\mathrm{Aa}}$ & -36 & $3120^{\mathrm{Aa}}$ & $-31,8$ & $2100^{\mathrm{Aa}}$ & -100 \\
Control & $1150^{\mathrm{Aa}}$ & $1366^{\mathrm{Aa}}$ & - & $1000^{\mathrm{Aa}}$ & - & $2366^{\mathrm{Aa}}$ & - & $1050^{\mathrm{Aa}}$ & -
\end{tabular}

Capital letters in the same column and lower case letters in the same line do not differ statistically $(\mathrm{P}>0,05)$.

In this study, the dosage of $1 \mathrm{~g} / \mathrm{kg}$ and $2 \mathrm{~g} / \mathrm{kg}$ of body weight in the animals was used for 28 consecutive days. However, Almeida et al. (2007) used $4,5 \mathrm{~g} / \mathrm{kg}$ of body weight in goats for only three consecutive. Even after the daily administration of the pellets for 28 days, there was an increase in OPG $143 \%$ and $100 \%$ the groups treated with $1 \mathrm{~g} / \mathrm{kg}$ to $2 \mathrm{~g} / \mathrm{kg}$, respectively.

Various studies have demonstrated the in vitro and in vivo anthelmintic action of $M$. charantia. Gomes et al. (2010) analyzing the action of its alcoholic extract in vitro on gastrointestinal nematodes' eggs in goats found that the percentage of viable eggs decreased to $41,9 \%$ after 72 hours of incubation. BritoJunior et al. (2011) observed anthelmintic activity of this plant when testing its alcohol extract in goats in semiarid region of Paraíba, obtaining reductions of $40 \%$ at 30 and 60 days post-treatment. Girão et al. (1998), who studied the action of $M$. charantia in the form of dried and ground branches on natural infections in goats, obtained an average percentage of reduction of $43 \%$.

The work with medicinal plants becomes difficult due the alterations that they suffer when in abiotic stress situations of their secondary metabolites (SM), chemical agents that act as nematicides, this being probably the cause of the plant's anthelmintic ineffectiveness. Beloin et al. (2005) stated that the anthelmintic effectiveness of the $M$. charantia's leaves is mainly due to SM denominated triterpen glycosides, as well as Mormodicines I and II, these being, the main nematicide agents. In addition, $M$. charantia presents tannins and catechins, secondary compounds that represent one of the means of plant defense (GOMES et al., 2011). The fertility and type of soil, humidity, solar radiation, wind, temperature and atmospheric pollution are factors that may influence and alter the chemical composition of plants. These described factors demonstrate the complexity of the strategy of utilization of the secondary metabolites obtained from plants (ALVES, 2001).

The percentages of genera of helminths observed in the fecal cultures are described in Table 2.

It was observed that the Haemonchus sp. was the most prevalent genus in the fecal cultures, followed for Strongyloides sp., Oesophagostomum sp. and Trichostrongylus sp. The prevalence of the genus Haemonchus sp. corroborates with the results obtained by Brito-Junior et al. (2011), when they carried out a comparative study of the anthelmintic action of Operculina hamiltonii and $M$. charantia in goats in semiarid region of Paraíba, and Vilela et al. (2009), who tested the sensitivity of gastrointestinal nematodes in sheep to Solanum paniculatum in the same region.

The predominance of the genus Haemonchus sp. in these researches is due to its high biotic potential, with a rapid and effective development, which contributes to their proliferation (ECHEVARRIA; TRINDADE, 1989).

The weight averages of the groups during the experiment are represented in the Figure 1.

No statistical differences $(\mathrm{P}>0,05)$ were observed throughout the experiment, on the weight of the animals treated with $M$. charantia pellets when compared to the control group. Despite this, it should be observed that there was a subtle increase in weight in the groups receiving the plant pellets: $1,3 \mathrm{~kg}$ in the group treated with $1 \mathrm{~g} / \mathrm{kg}$ and $0,4 \mathrm{~kg}$ in the treated with $2 \mathrm{~g} / \mathrm{kg}$. In the control group, there was an average reduction of $0,5 \mathrm{~kg}$. 
Table 2 - Percentage of genera of helminths in fecal cultures obtained from naturally infected goats and treated with $M$. charantia pellets in the Brazilian semiarid.

\begin{tabular}{|c|c|c|c|c|c|c|}
\hline Groups & & $\begin{array}{c}\text { Day 00 } \\
(\%)\end{array}$ & $\begin{array}{c}\text { Day } 07 \\
(\%)\end{array}$ & $\begin{array}{c}\text { Day } 14 \\
(\%)\end{array}$ & $\begin{array}{c}\text { Day } 21 \\
(\%)\end{array}$ & $\begin{array}{c}\text { Day } 28 \\
(\%)\end{array}$ \\
\hline & $\mathrm{H}$ & 75 & 65 & 50 & 83 & 52 \\
\hline M. charantia & $\mathrm{T}$ & 0 & 0 & 0 & 0 & 01 \\
\hline \multirow[t]{3}{*}{$1 \mathrm{~g} / \mathrm{kg}$} & $\mathrm{O}$ & 0 & 0 & 0 & 0 & 02 \\
\hline & $\mathrm{S}$ & 25 & 35 & 50 & 17 & 45 \\
\hline & $\mathrm{H}$ & 100 & 70 & 75 & 46 & 81 \\
\hline M. charantia & $\mathrm{T}$ & 0 & 0 & 0 & 0 & 0 \\
\hline \multirow[t]{3}{*}{$2 \mathrm{~g} / \mathrm{kg}$} & $\mathrm{O}$ & 0 & 5 & 0 & 4 & 19 \\
\hline & $\mathrm{S}$ & 0 & 25 & 25 & 50 & 0 \\
\hline & $\mathrm{H}$ & 83 & 84 & 75 & 96 & 84 \\
\hline \multirow{3}{*}{ Control } & $\mathrm{T}$ & 0 & 02 & 0 & 0 & 04 \\
\hline & $\mathrm{O}$ & 17 & 04 & 0 & 04 & 12 \\
\hline & $\mathrm{S}$ & 0 & 10 & 25 & 0 & 0 \\
\hline
\end{tabular}

$\mathrm{H}=$ Haemonchus $\mathrm{sp} . \mathrm{T}=$ Trichostrongylus sp. $\mathrm{O}=$ Oesophagostomum $\mathrm{sp} . \mathrm{S}=$ Strongyloides

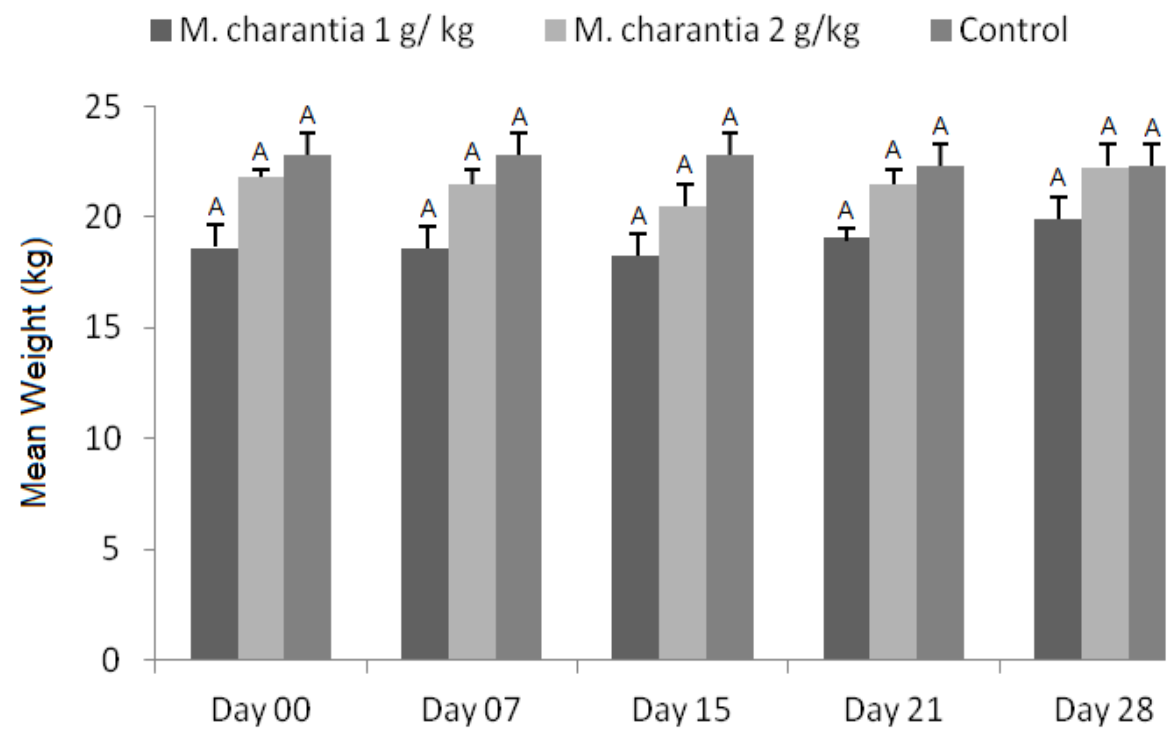

Figure 1 - Arithmetic averages and standard deviation of the live weight of goats in groups M. charantia $1 \mathrm{~g} / \mathrm{kg}$, M. charantia $2 \mathrm{~g} / \mathrm{kg}$ and Control. The Values followed by equal letters are similar (P>0,05) - Tukey test at 5\% probability.

According to Barreto et al. (2011), the supply of diets with high energy level favors the food and rumination efficiency, and a better weight gain occurs in ruminants. In this case, since there was no reduction in the animals' parasite load and, consequently, there was no reduction of the helminths' hematophagous action, the administration of molasses powder may explain the weight gain of the treated groups. Baytok et al. (2005) also reported that molasses rapidly stimulate lactic fermentation in the rumen by increasing the production of volatile fatty acids, very important for the energy supplement.

\section{CONCLUSION}

The pelletized formulation facilitated the administration of $M$. charantia however was not effective in controlling the gastrointestinal helminths of goats naturally infected Paraíba semiarid.

\section{REFERENCES}

ALMEIDA, W. V. F.; SILVA, M. L. C. R.; FARIAS, E. B.; ATHAYDE, A. C. R.; SILVA, W. W. Avaliação de plantas medicinais em caprinos da região do semiárido paraibano naturalmente infectados por nematóides gastrointestinais. Caatinga, Mossoró, v. 20, n. 3, p. 01-07, 2007.

ALVES, H. M. A diversidade química das plantas como fonte de fitofármacos. Cadernos Temáticos de Química Nova na Escola, São Paulo, n. 3, p. 10-15, 2001.

BARRETO, L. M. G.; MEDEIROS, A. N.; BATISTA, A. M. V.; FURTADO, D. A.; ARAÚJO, G. G. L.; LISBOA, A. C. C.; PAULO, J. L. A.; SOUZA, C. M. $\mathrm{S}$. Comportamento ingestivo de caprinos das raças Moxotó e Canindé em confinamento recebendo dois níveis de energia na dieta. Revista Brasileira de

Zootecnia, Brasília, v. 40, n. 4, p. 834-842, 2011. 
BAYTOK, E.; AKSU, T.; KARSLI, M. A.; MURUZ, $\mathrm{H}$. The effect of formic acid, molasses and inoculant as silage additives on corn composition and ruminal fermentation characteristics in sheep. Turkish Journal of Veterinary Animal Science, Ankara, v. 29, p. 469474, 2005.

BELOIN, N.; GBEASSOR, M.; AKPAGANA K.; HUDSON, J.; SOUSSA, K.; KOUMAGLO, K.; ARNASON, J. T. Ethonomedicinal uses of Mormodica charantia (Curcubitaceae) in Togo and relation to its phytochemistry and biological activity. Journal Ethnopharmacol, Leiden, v. 29, p. 49-55, 2005.

BRITO-JÚNIOR, L. B.; SILVA, M. L. C. R.; LIMA, F. H.; ATHAYDE, A. C. R.; SILVA, W. W.; RODRIGUES, O. G. Estudo comparativo da ação antihelmíntica da batata de purga (Operculina hamiltonii) e do Melão de São Caetano (Mormodica charantia) em caprinos (capra hircus) naturalmente infectados. Ciência e Agrotecnologia, Lavras, v. 35, n. 4, p. 797 802, 2011.

CORDEIRO, L. N.; ATHAYDE, A. C. R.; VILELA, V. L. R.; COSTA, J. G. M.; SILVA, W. A.; ARAUJO, M. M.; RODRIGUES, O. G. Efeito in vitro do extrato etanólico das folhas do melão-de-São-Caetano (Momordica charantia L.) sobre ovos e larvas de nematóides gastrintestinais de caprinos. Revista Brasileira de Plantas Medicinais, Botucatu, v. 12, n. 4, p. 421-426, 2010.

ECHEVARRIA, F. A. M.; TRINDADE, G. N. P. Anthelmintic resistance by Haemonchus contortus to ivermectin in Brazil. Veterinary Record, Londres, v. 124, p. 147-148, 1989.

GIRÃO, E. S.; CARVALHO, J. H.; LOPES, A. S. Avaliação de plantas medicinais com efeito antihelmíntico para caprinos. Embrapa, Brasília, n. 78, p. 1-9, 1998.

GETACHEW, G. Tannins in tropical multipurpose tree species: localization and quantification of tannins using histochemical approaches and the effect of tannins on in vitro rumen fermentation. Verlag Ulrich E. Grauer, Stuttgart, p. 186, 1999.

GOMES, R. V. R. S.; ARAÚJO, M. M.; GOMES, E. N.; VILELA, V. L. R.; ATHAYDE, A. C. R. Ação antiparasitária in vitro dos extratos etanólicos de Operculina hamiltonii (batata de purga) e Momordica charantia (melão de são caetano) sobre ovos e larvas de nematóides gastrintestinais de caprinos do semiárido paraibano. Acta Veterinaria Brasilica, Mossoró, v. 4, n. 2, p. 92-99, 2010.
GOMES, R. V. R. S.; VILELA, V. L. R.; GOMES, E. N.; MAIA, A. J.; ATHAYDE, A. C. R. Análise fitoquímica de extratos botânicos utilizados no tratamento de helmintoses gastrintestinais de pequenos ruminantes. Revista Caatinga, Mossoró, v. 24, n. 4, p. 172-177, 2011.

GORDON, H. M.; WHITLOCK, H. V. A new technique for counting nematode eggs in sheep faeces. Journal Council Science Industry Research, New Delhi, v. 12, p. 50-52, 1939.

LIMA, M. M.; FARIAS, M. P. O.; ROMEIRO, E. T.; FERREIRA, D. R. A.; ALVES, L. C.; FAUSTINO, M. A. G. Eficácia da moxidectina, ivermectina e albendazole contra helmintos gastrintestinais em propriedades de criação caprina e ovina no Estado de Pernambuco. Ciência Animal Brasileira. Goiânia, v. 11, n. 1, p. 94-100, 2010.

MELO, L. R. B.; VILELA, V. L. R.; FEITOSA, T. F.; ALMEIDA NETO, J. L.; MORAIS, D. F. Resistência anti-helmíntica em pequenos ruminantes do semiárido da Paraíba, Brasil. ARS Veterinária. Jaboticabal, SP, v. 29, n.2, 104-108, 2013.

MOLENTO, M. B. Resistência de helmintos em ovinos e caprinos. Revista Brasileira de Parasitologia Veterinária, Jaboticabal, v. 13, n.1, 2004. Suplemento.

ROBERTS, F. H. S.; O' SULLIVAN, J. P. Methods of egg couts and laval cultures for strongyles infesting the gastrointestinal tract of cattle. Australian Agriculture Research, Bruce, v. 1. p. 99-102, 1950.

VIEIRA,V. D.; FEITOSA, T. F.; VILELA, V. L. R.; AZEVEDO, S. S.; ALMEIDA NETO, J. L.; MORAIS, D. F.; RIBEIRO, A. R.; ATHAYDE, A. C. R. Prevalence and risk factors associated with goat gastrointestinal helminthiasis in the Sertão region of Paraíba State, Brazil. Tropical Animal Health and Production, Edinburgh, v. 46, p. 355-361, 2014.

VILELA, V. L. R.; FEITOSA, T. F.; LÔBO, K. M. S.; BEZERRA, D. A. C.; ATHAYDE, A. C. R. Potencial anti-helmíntico da raiz de Solanum paniculatum Linnaeus (1762) em ovelhas do semi-árido paraibano. Acta Veterinaria Brasilica, v. 3, n. 1, p. 20-24, 2009. região metropolitana de Curitiba, Paraná. Arquivos do Instituto Biológico, v.77, n.3, p.511-515, 2010. 